\title{
Constitutional Democracy for Divided Societies: The Indonesian Case
}

\author{
Munafrizal Manan \\ Faculty of Social and Political Sciences, University of Al-Azhar Indonesia \\ Jalan Sisingamangaraja, Kebayoran Baru, Jakarta 12110, Indonesia \\ Tel: 62-21-7279-2753 E-mail: munafrizal2003@yahoo.com
}

\begin{abstract}
To build a democracy is to choose a model of democracy. Countries that are building their democracy have often been faced to choose a model of democracy that is suitable to their particular needs. Theoretically and practically, there are some models of democracy. This article discusses the prospect of constitutional democracy for divided societies by putting constitution as a social contract for them. It argues that if a common consensus for a constitution has been reached, then the prospect of a harmonized society can be realized since people have a common platform that binds them legally, politically and socially. By taking Indonesia as a case, it argues that constitutional democracy is relatively able to overcome potential conflict in a divided society. Thus constitutional democracy should be considered as a resolution for divided societies.
\end{abstract}

Keywords: Constitution, Democracy, Constitutional Democracy, Divided Society, Multicultural, Horizontal Conflict

\section{Introduction}

The attention to democracy, both theoretically and practically, has been increasing significantly since 'the third wave' of democratization has begun in 1974 (Huntington 1991). According to Samuel Huntington (1991), during 1970s to 1990s, more countries have moved to democracy, hence it emerges the optimistic view about the future of democracy, or more precisely liberal democracy. For Francis Fukuyama, it expresses the victory of liberal democracy over its ideological rivals (authoritarianism and totalitarianism), by which he believes that 'the end of history' is coming (Fukuyama 1992). Since then democracy has been becoming more popular and even to be an influential factor in international relations.

Apart from the emerging democracy in the world, it is thought that enforcing democracy is not an easy task for a country which is divided deeply into race, ethnicity, religion, language, culture, gender, and social stratification differences. Rather than offers a positive thing, moving to democracy potentially stimulates tension and even horizontal conflicts among societies who have such different backgrounds. Jack Snyder, for example, shows that the early phase of democratization has triggered nationalistic conflicts in some countries (Snyder 2000). This is a reason why democracy fails in countries which have a plural society. Moreover, democracies also tend to fail in weak capacity states as it has been occurring in third-wave democracies (Dominguez and Jones 2007, 7; Tilly 2007, 15-21).

Given this fact, what kind of democracy is more suitable for a divided society? The scholars of political science have been discussing such a question and some of them have tried to offer a remedy for a divided society. This essay will review briefly this discussion and then take a standing point that constitutional democracy should be considered for a divided society. It begins by discussing the suitability of several types of democracy for a divided society and then examining it in the case of Indonesia.

\section{Types of Democracy}

There are various types of democracy that has been introduced by scholars that indicates there are many views on democracy (for example, Held 1987; Heywood 1997).

Electoral democracy emphasizes the importance of universal suffrage right in which one person has one vote. Electoral democracy defines democracy merely as giving vote in elections in order to choose public officers to represent people's interests (Schumpeter 1987). In this regards, electoral democracy has a close relation with representative democracy. The problem with these democracies is inclined to benefit majority and neglect minority. In such democracies, the will of the majority must be obeyed (Mueller 1997, 84). It is believed that if a competition is solely based on the number of votes then minority will lose. Therefore, these kinds of democracies are not enough for a divided society.

For this reason, electoral democracy should be combined with another type of democracy so that it is suitable for a divided society. Arend Lijphart (1977) offers what he calls consociational democracy for divided societies. He sketches favourable conditions for consociational democracy. He and other scholars pay much attention to the importance of constitution to make democracy works properly (Lijphart 2004; Horowitz 2000; Issacharoff 2004; Reynolds 2005). 
Deliberative democracy is another type for a plural society. Theorists of deliberative democracy argue that democratic process should open spheres for public involvement in policy-making that related to public interest or common good (Chambers 2003). Deliberative democracy is useful to prevent the domination of majority group in democratic process and give an opportunity to minority or marginalized groups to voice their interests. Deliberative democracy is a remedy to reconcile the clash between democracy and right as well as between the majority will and individual rights (Chambers 2003, 311). Some theorists of deliberative democracy stress the importance of rule of law and constitutional rights (Chambers 2003, 309-11), but less attention has been paid to the relationship between deliberative democracy and constitution. Although between deliberative democracy and constitutional democracy seems has a similar idea, the main attention of deliberative democracy is not to constitution, but rather to how people have an equal opportunity in democratic process.

No doubt that democracy is a complicated one so it is somewhat difficult to claim that one type of democracy is better than the other types. In practice, it is common to apply a mixed type of democracy to complement each other. However, democracies for divided societies should be poured clearly into a constitution. A well-functioning democracy in a divided society requires a constitution.

Constitutional democracy is necessary for divided societies as it regulates and guarantees the enforceability of democracy for a divided society. Any type of democracy can be called constitutional democracy as long as it is stipulated by a constitution. Constitutional democracy is a big umbrella and the other types as its branch. Democracy constitutional is as primes inter pares among other types.

\section{Constitutional Democracy}

Literally, constitutional democracy is the combination of constitutionalism and democracy terms. Thus it is useful to see what constitutionalism and democracy are.

The Oxford English Dictionary explains that the first use of the word "constitutionalism" was in 1832 (Gordon 1999, 5). According to Jon Elster, constitutionalism is "to limits on majority decisions, more specifically, to limits that are in some sense self-imposed" (Elster, 1988, 2). Scott Gordon argues that the notion of constitutionalism refers to "the coercive power of the state is constrained" (Gordon 1999, 5). For Gordon, what is the most important of constitutionalism is "the problem of controlling the power to coerce" (Gordon 1999, 7 original emphasis).

Meanwhile, the original of word "democracy" is from the Greek which consist of two words, these are demos (the people) and kratos (rule or authority) (Gordon 1999, 60). The simple and popular definition of democracy has been introduced by Abraham Lincoln who argued that democracy is a government from people, by people, and for people. According to Charles Tilly, "a regime is democratic to the degree that political relations between the state and its citizens feature broad, equal, protected and mutually binding consultation" (Tilly 2007, 13-4 original emphasis).

In discussing constitutional democracy, some scholars argue that there is a tension between democracy (democrats) and constitutionalism (constitutionalists). Such a tension has appeared in $18^{\text {th }}$ century and probably earlier than that (Holmes 1988, 198). One of the historical debates on constitutionalism and democracy is the debate between Thomas Jefferson and James Madison (Sunstein 1988, 327).

Democracy allows a political competition by which a decision is made based on majority power. By contrast, constitutionalism limits majority rule which potentially lead to majority tyranny. Moreover, to use Walter Murphy words, "whereas democratic theory turns to moral relativism, constitutionalism turns to moral realism" (Murphy 1993, 6). Therefore, those who believe that there is a tension between the two argue that "constitutional democracy is a marriage of opposites, an oxymoron" (Stephen Holmes 1988, 197).

However, other scholars rebut such a view. Cass Sunstein argues that "there is no inevitable tension between democracy and constitutionalism" (Sunstein 1988, 353). Similarly, Jon Elster also believes that constitutional constraints on democracy are the way to strengthen democracy itself (Elster 1988, 9). Stephen Holmes comes to the same view that "constitutionalism and democracy are mutually supportive" and therefore he argues the tension between two is a myth of modern political thought (Holmes 1988, 197). I agree with these views because between the two should not be contrasted or, to quote Walter Murphy, "one must not exaggerate their differences" (Murphy 1993, 6). Basically, constitutional democracy tries to complement the weaknesses of constitutionalism and democracy by combining them. In addition, as Dennis Mueller argues, "all democracies have constitution" (Mueller 1997, 64) which indicates that has a close relation between constitutionalism and democracy. (Note 1)

Constitutional democracy is able to overcome potential conflicts in divided societies. However, it is important to note that what is meant by constitutional democracy here is not only based on the existence of a constitution, but also a constitution that regulates and guarantees the balance of majority and minority relationship. (Note 2) It is needed to prevent the potential tension and conflict in divided societies. Thus the existence of a constitution is a necessary condition, but it is not a sufficient condition unless it is not intended to enforce the harmony and stability of divided societies. 
Constitutional democracy has a more power in enforcing the stability and harmony in divided societies compared to other types of democracy because constitution is a supreme law. As the fundamental and the highest law, constitution is the heart of power. Constitution is very important for all parties in divided societies because, as Dennis Mueller argues, "the constitution is a sort of social contract" and "the rules under which all future political games are to be played" (Mueller 1996, 61 \& 63). In addition, as Walter Murphy argues, constitutional democracy "accept the centrality of human dignity" (Murphy, 1993, 6) which is very useful for divided societies. In short, constitutional democracy implies that democracy should be based on constitutional legitimacy, and, conversely, constitution should be a democratic constitution.

Constitutional democracy has been a global phenomenon. Walter Murphy argues that "many countries have adopted a mix of constitutionalism and democracy theory" (Murphy 1993, 6). Most countries around the world which so-called democratic systems basically should be sorted as constitutional democracies (Murphy 1993, 6). It obviously shows the omnipresence of constitutional democracy.

A good constitutional design affects the enforceability of constitutional democracy in divided societies. In this regards, a constitution should be a democratic constitution in which fulfil the principles of constitutional democracy. Democratic constitution is needed to provide the framework of a good relationship among societies in the future. Constitutional drafters should consider the plurality of society in making a constitution. A constitution should be made by accommodating different interests and perspective in divided societies, both majorities and minorities (Dominguez and Jones 2007, 7). There should be the recognition of pluralism as well as the recognition of minority rights.

Constitution is a crucial aspect of enforcing and stabilizing new democracy. The process of transition to democracy should be followed by the (re)construction of democratic constitution. The (re)construction of a democratic constitution is a starting point to democracy. This is a reason why almost all new democratic states put constitutional amendment into the top priority to build and maintain democracy. These states reform their constitution soon after the fall of the authoritarian regimes. The undemocratic constitution that inherited from an authoritarian regime is replaced by a democratic constitution.

An effort to anticipate potential conflict in divided societies should be started from constitution. However, the constitutional making in transitional democracies is not easy task to do. All parties have to agree to achieve constitutional settlements in which it requires constitutional negotiation among them. The constitutional negotiation can lead to the deadlock (constitutional crisis) if each party only focus on their own interests, particularly if there are adversarial interests between the majority and minority. To be clear, it is hard to reconcile between the need for constitutional constraints on the majority and the desire the majority to become dominant. It is also difficult to balance between "empowering majorities and ensuring the representation and participation of minorities in national decision making" (Simeon and Turgeon 2007, 87). The experiences of democratization process in Eastern and Central Europe and in Africa have showed that the most important challenge for deeply divided societies is to balance properly between unity and diversity (Simeon and Turgeon 2007, 82), and it is commonly related to the relationships between the majority and minority.

The failure of reconciling the tension between the majority and minority potentially lead to what Richard Simeon and Luc Turgeon call insecure majority, a condition in which the majority "represses or dominates the minority" and insecure minority, a condition in which the minority "rebels or secedes" (Simeon and Turgeon 2007,82 original emphasis). Conversely, the success of reconciling the tension between majority and minority will guarantee the consolidation of democracy. This is why, as Richard Simeon and Luc Turgeon argue, "making a constitution, especially in divided societies, warrants careful statecraft" (Simeon and Turgeon 2007, 93). If a common consensus for a constitution has been reached, then the prospect of a harmonized society can be realized since people have a common platform that binds them legally, politically, and socially. Based on this, the abuse of a common platform will be judged unconstitutional.

\section{The Case of Indonesia}

The following sections try to examine such a thesis for Indonesian case. Constitutional democracy has played a key role in the making and preservation of the Republic of Indonesia but it is still a problem to cope with horizontal conflicts among divided societies. Firstly, it describes the portrait of the Republic of Indonesia as a multicultural country. Secondly, it highlights historical context in which constitutional consensus has played an important role in Indonesian history. It also draws that the living constitution, which indicates that constitutional consensus is working in reality, is now still far from ideal hope.

\subsection{A Multicultural Country}

Indonesia is an archipelagic country which is located in Southeast Asia. There are several ways to identify Indonesian characteristics. Seen from its population which is estimated at about 220 million today, Indonesia is the fourth largest 
country in the world as well as the most populous Muslim country around the globe with approximately 90 per cent of its population is Muslims.

Regarding its geographic region, Indonesia is composed of 19,000 islands, both large and small islands, across the equator. Adrian Vickers analogizes that "[a]s a country joined by water, Indonesia covers an area as wide as Europe or the United States" (Vickers 2005, 1). Historically, the territorial boundaries of Indonesia are based on the islands that had ever been colonized by the Netherlands.

In political development context, following the fall of the authoritarian power of President Suharto on 21 May 1998, Indonesia now is also mentioned as the third largest democratic country in the world after the United States and India. In this context, it should be noted that politically and historically Indonesian politics has been fragmented by a number of ideologies or political streams (Feith and Castles 1970; Bourchier and Hadiz 2003) which representing the diversity of culture of Indonesia. To be sure, ideological conflicts have been a challenge to the prospect of Indonesian democracy. As Bourchier and Hadiz $(2003,2)$ note, "[c]onflict over ideology has been a feature of political life in Indonesian since the early days of the nationalist movement'. Such a conflict had occurred during 1950s in which there was a strong competition between those who wanted "to reform society along Islamic or communist lines" and "who wanted to follow the example of a Western Democracy" (Dijk 1990, 102).

In dealing with the plurality of culture, Indonesia is well-known as a multicultural country in which there are at least 300 ethnic groups and 200 different languages on the islands (Geertz 1967, 24 cited in Dijk 1990, 101). Each of these ethnic groups has its own cultural life including music, theatre, the visual arts, poetry and literature, and so on (Vickers $2005,2)$. There are some religions in Indonesia which is consist of the major religions such as Islam, Catholic, Protestant, Hindu, and Buddha, and other spiritual faiths or religious sects. This is the cultural richness of Indonesia. However, like other multicultural countries, it can be a source of tension and conflict.

According to Vickers, "[t]his diversity and depth of Indonesian culture is a product of openness to new ideas and practice" (Vickers 2005, 2). Similarly, Dennis Lombard (1996) has revealed that Indonesian cultures had been influenced by India, Chinese, the West, and Islamic civilizations. Such a view has also been expressed by historians J. D. Legge (1977) and M. C. Ricklefs (1993). Indonesia, indeed, is a country that welcome to other cultural influences.

\subsection{Constitutional Consensus and Horizontal Conflicts}

As a multicultural country, the diversity of ethnic groups has been a crucial issue. J. D. Legge has noted that "[o]ne of Indonesia's major problem in the modern world is that of merely preserving the unity of the nation" (Legge 1977, 3). No doubt that it is difficult to unite them in a nation-state as well as to accommodate their values, ideologies, and interests in which sometimes opposite sharply to each other. In the words of Vickers, "it has struggled to balance the interests of different groups and maintain coherence against both the pressure of its own diversity and tensions created by international politics" (Vickers 2005, 3).

Indeed, how to reconcile the big (the majority) and the small (the minority) ethnic groups so that they can live side by side peacefully and equally is an enduring question in Indonesian history. Such an issue had emerged since the very beginning when a nation-state called Indonesia was being discussed by the founding fathers and mothers in 1940s. It was, therefore, an extraordinary achievement since they were able to persuade and unite people with different backgrounds in order to create an, to use the phrase of Benedict Anderson (1983), "imagined community" namely the Republic of Indonesia.

There are two factors, at least, that has contributed to achieve a unified Indonesia. Firstly, the similar feeling among Indonesian people that the Dutch colonialist was a common enemy for them. Such a sentiment, which was raised frequently by nationalists during the Independence Revolution, had united people to against the Dutch colonialist. Today, this factor has become history.

Secondly, Indonesian language, called Bahasa Indonesia, has an important role in unifying Indonesian people who have different languages. It is important to note that Indonesian language was and is not taken from the largest number of speakers, such as Javanese, but it was adopted from Malay language which was used by minor people on the Riau islands. Malay is as the lingua franca at that time and, unlike Javanese, an egalitarian language which was relatively easy to be learnt and accepted by other ethnic groups. The use of Malay as a national language is the way to avoid the dominance of major culture in Indonesia. Although Malay has long been accepted as national language, it is just recently, in the Second Amendment in 2000, its status has been incorporated into the 1945 Constitution of the Republic Indonesia. To be certain, Bahasa Indonesia has been a constitutional consensus for Indonesian people.

Looking back to the history, it can be argued that the constitutional consensus has played a very important role in the making of a nation-state namely the Republic of Indonesia. Soon after the Independence Proclamation had been proclaimed by Sukarno and Mohammad Hatta on 17 August 1945, which marked the Republic of Indonesia has just been established, the founding fathers and mothers had discussed seriously about the Constitution for the new Republic. They almost failed to achieve a consensus because there was a disagreement over the national ideology. Some strongly 
defended Islam as national ideology, while others endorsed the Pancasila (the Five State Principles) which are consist of believe in one supreme God, just and civilized humanity, national unity, democracy led by wisdom and prudence through consultation and representation, and social justice. In such a constitutional crisis, the prospect of the new Republic was under serious threat because "regions where Christian or Hindus formed the majority of the population would refuse to join the Republic" (Dijk 1990, 107). Fortunately, constitutional consensus eventually could be achieved and, as a result, Indonesia is not an Islamic state though ninety per cent of the population is Muslims. Moreover, other religious minorities did not feel like second-class citizens (Cribb and Brown 1995, 38). The constitutional consensus, in this case, was a remedy for divided societies as Indonesia.

It is useful to note that the proponents of an Islamic state keep struggling tirelessly to achieve their vision. They have been urging a constitutional amendment or re-apply the Jakarta Charter "which would have obliged the state to impose Islamic law on all its Muslim citizens" (Cribb and Brown 1995, 38). The Jakarta Charter has been believed by them as the justification of an Islamic state for Indonesia.

There were two momentums in Indonesian history after the Independence Revolution in which the proponents of an Islamic state have tried to reach their vision. Firstly, it had emerged in the second half of 1950s in which the Constituent Assembly members were drafting a permanent constitution to replace the 1950 provisional constitution (Legge 1977, 155). These members could not reach a constitutional consensus of national ideology as it had ever occurred in the early year of the new Republic in 1945. As a result, there was the deadlock of constitution-making which means the national unity was in a serious threat. To cope with this, President Sukarno who was supported by the Indonesian Military and moderate Muslims dissolved the Constituent Assembly and promulgated a return to the 1945 Constitution- the Constitution which had been adopted by the new Republic after its Independence Proclamation - by the presidential decree on 5 July 1959, which brought Indonesia into Sukarno's "Guided Democracy" after that date. Even though the presidential decree was unconstitutional decision (Legge 1977, 156; Nasution 1992; Ricklefs 1993, 266)), in fact it is widely admitted that it was an acceptable solution to get out of the constitutional impasse and prevent national disunity.

Secondly, the proponents of an Islamic state had also echoed their vision when constitutional amendments were taking place from 1999 to 2002. However, it was only voiced by a few people and not supported by the vast majority of Indonesian people, even by Muslims themselves. Consequently, they have failed again.

Even today there are still people who think that Indonesia should be an Islamic state because the majority of the population is Muslims. Nevertheless, it seems that the majority have agreed with the Pancasila ideology compared to other ideologies as it is generally believed that the Pancasila is able to facilitate a unity in diversity, called Bhinneka Tunggal Ika in Indonesian language. The Pancasila is, essentially, the middle way to accommodate all Indonesian people who have different cultures. Generally speaking, most Indonesian people today believe that such a constitutional consensus is final and, therefore, no more ways to change it. They believe that the 1945 Constitution is necessary to preserve the national unity, although the 1945 Constitution was not truly a democratic constitution until it has been amended from 1999 to 2002. As a consequence, the opponents of the Pancasila are alienated and they are judged unconstitutional because they reject the constitutional consensus.

However, it is not saying that the constitutional consensus is the panacea and therefore able to stop horizontal conflicts as such conflicts remain potential as well as actual even today, although the constitutional consensus has been reached.

Many horizontal conflicts, which were triggered by religious, ethnic, economy, and political reason, have occurred which indicates that such conflicts are still a big issue. Historically, each different ethnic group has lived together in harmony and peaceful for a long time. Sociologically, they have a sense of toleration of differences. Because of this, Indonesia has been well-known as a tolerant country. However, many people have been shocked by violence conflicts that had suddenly erupted in some regions in the years following the fall of President Suharto who had banned to discussing sectarianism issues - called SARA, an acronym for the words suku, agama, ras and antargolongan (ethnic group, religion, race and intergroup relations) - in the media during his power era for more than three decades.

Gerry van Klinken's study illustrates communal violence that occurred in several places across Indonesia between 1997 and about 2002, these are West and Central Kalimantan, Central Sulawesi, Maluku/Ambon and North Maluku (Klinken 2007). Similarly, the study of Chris Wilson focuses on the bloody religious conflicts between Christian and Muslims in North Maluku from 1999 until 2000 (Wilson 2008). All these are evidence that horizontal conflicts are still a serious matter in a multicultural country like Indonesia. However, it is too narrow to conclude that all horizontal conflicts were triggered solely by cultural differences. In some cases, horizontal conflicts have been triggered by the competition of the resources, particularly dealing with economy and political issues, among societies. Undoubtedly, such a competition has likely been to bring them into conflicts. In some cases, primordial and religious sentiments are exploited to cover such a motive. Indeed, primordial and religious sentiments are likely to be effective ways to mobilize the mass solidarity. 
After all, horizontal conflicts show the paradox of Indonesian country because they have been occurring when the democratic process was going and people have more liberties and equalities than before, in which they have been guaranteed by the 1945 Constitution and laws. Furthermore, the guarantee of constitutional rights has been extended both its quantities and qualities after the amendment of the 1945 Constitution for four times (from 1999 to 2002). Besides, the establishment of the new state body namely the Constitutional Court of the Republic of Indonesia in 2003 allow people to defend their constitutional rights before the Court. In short, there is no more reason for horizontal conflicts under such constructive conditions. In fact, it shows that the constitutional consensus "is not conceived as a binding instrument" (Hassall and Saunders 2002, 3).

In the context of the constitutional consensus, it obviously shows that the living constitution is still a struggle in Indonesia. The Constitution is very good in theory but remain very poor in practice. Moreover, the constitutional awareness tends to be limited to the elite level, but it does not reach the mass level. As in the period of constitutional democracy between December 1949 and March 1957 in which "[m]ost members of the political elite had some sort of commitment to symbols connected with constitutional democracy" (Feith 1962, xi) —although they had faced challenges to applied it in a reality - elites today also have the same commitment to constitutional democracy. Unfortunately, such a commitment has not been disseminated widely to the mass level. It indicates that, in the words of Hassall and Saunders $(2002,241)$, "[t]he language of the law' is not that of 'the people",.

\section{Conclusion}

This article has argued that there is a strong reason to weigh constitutional democracy for divided societies. Seen from its status as the supreme law, constitution is a starting point to building a mutual-understanding relationship among divided societies. But it is, indeed, not an easy task to reach a constitutional consensus in divided societies.

This article has also attempted to examine how constitutional democracy has been applied as well as how the constitutional consensus has been achieved in Indonesia. Indonesia is a relevant country to see the application of constitutional democracy for divided societies since it is a multicultural country in various aspects. Such a multicultural reality can bring both positive and negative impacts. In a positive view, it is a rich diversity of cultures. In negative view, it is a potential source for horizontal conflicts.

If it is dealing with the making and the preservation of the Republic of Indonesia, people could come to the constitutional consensus. In this context, to use Dijk's words, 'Indonesia remain[s] an unbreakable political entity' and 'has forged a remarkably strong unity from the diversity of separate ethnic groups' (Dijk 1990, 106 \& 125). Even so, it is hard to bring the constitutional consensus into the social relationships among divided societies because horizontal conflicts which exploit religious and primordial sentiments are still appear in Indonesian societies. In sum, to some extent, constitutional democracy for divided societies has been working in the case of Indonesia. Yet it still needs a time to celebrate it.

\section{References}

Anderson, B. R. O'G. (1983). Imagined Communities: Reflections on the Origins and Spread of Nationalism. London: Verso.

Bourchier, D., \& Hadiz, V. R. (2003). Indonesian Politics and Society: A Reader. London: Routledge Curzon.

Chambers, S. (2003). Deliberative Democratic Theory. Annual Review of Political Science 6, 307-326.

Cribb, R., \& Brown, C. (1995). Modern Indonesia: A History since 1945. London and New York: Longman Group Limited.

Dijk, K. van. (1990). The Indonesian State: Unity in Diversity. In S. K. Mitra (Ed.). The Post-Colonial State in Asia: Dialectics of Politics and Culture. Hemel Hempstead: Harvester Wheatsheaf.

Dominguez, J. I., \& Jones, A. (2007). Building and Sustaining a Contemporary Democratic State. In J. I. Dominguez, \& A. Jones (Eds.), The Construction of Democracy: Lessons from Practice and Research. Baltimore: The Johns Hopkins University Press.

Elster, J. (1988). Introduction. In J. Elster, \& R. Slagstad (Eds.), Constitutionalism and Democracy. Studies in Rationality and Social Change. Cambridge: Cambridge University Press.

Feith, H. (1962). The Decline of Constitutional Democracy in Indonesia. Itacha, New York: Cornel University Press.

Press.

Fukuyama, F. (1992). The End of History and the Last Man. London: Hamish Hamilton.

Gordon, S. (1999). Controlling the State: Constitutionalism from Ancient Athens to Today. Cambridge, Massachusetts, and London: Harvard University Press. 
Hassall, G., \& Saunders, C. (2002). Asia-Pacific Constitutional Systems. Cambridge: Cambridge University Press.

Held, D. (1987). Models of Democracy. Stanford, California: Stanford University Press.

Heywood, A. (1997). Politics. Houndmills, Basingstone, Hampshire and London: MacMillan Press.

Holmes, S. (1988). Precommitment and the Paradox of Democracy. In J. Elster, \& Rune Slagstad (Eds.), Constitutionalism and Democracy. Studies in Rationality and Social Change. Cambridge: Cambridge University Press.

Horowitz, D. (2000). Constitutional Design: An Oxymoron. In I. Shapiro, \& S. Macedo (Eds.), Designing Democratic Institutions. New York and London: New York University Press.

Huntington, S. P. (1991). The Third Wave: Democratization in the Late Twentieth Century. Norman: University of Oklahoma Press.

Issacharoff, S. (2004). Constitutionalizing Democracy in Fractured Societies. Journal of International Affairs, Fall, Volume 58, No. 1, 73-93.

Klinken, G. van. (2007). Communal Violence and Democratization in Indonesia: Small Town Wars. Oxon: Routledge.

Legge, J. D. (1977). Indonesia. (2nd ed.). Sydney: Prentice-Hall of Australia Pty.

Lijphart, A. (1977). Democracy in Plural Societies. A Comparative Exploration. New Haven and London: Yale University Press.

96-109. (2004). Constitutional Design for Divided Societies. Journal of Democracy, Volume 15, Number 2, April,

Lombard, D. (1996). Nusa Jawa Silang Budaya. Jakarta: Gramedia Pustaka Utama.

Mueller, D. C. (1996). Constitutional Democracy. Oxford: Oxford University Press.

(1997). Constitutional Democracy: An Interpretation. In A. Breton, et.al.. Understanding Democracy: Economic and Political Perspectives. Cambridge: Cambridge University Press.

Murphy, W. F. (1993). Constitutions, Constitutionalism, and Democracy. In D. Greenberg, et.al (Eds.), Constitutionalism and Democracy: Transition in the Contemporary World: The American Council of Learned Societies Comparative Constitutionalism Papers. Oxford: Oxford University Press.

(1997). Constitutional Democracy: An Interpretation. In A. Breton, et.al (Eds.), Understanding Democracy: Economic and Political Perspectives. Cambridge: Cambridge University Press.

Nasution, A. B. (1992). The Aspiration for Constitutional Government in Indonesia: A Socio-Legal Study of the Indonesian Konstituante 1956-1959. Jakarta: Pustaka Sinar Harapan.

Reynolds, A. (2005). Constitutional Medicine. Journal of Democracy, Volume 16, Number 1, January, 54-68.

Ricklefs, M. C. (1993). A History of Modern Indonesia since c. 1300. (2nd ed.). Hampshire and London: the Macmillan Press.

Schumpeter, J. A. (1987). Capitalism, Socialism and Democracy. London: Unwin Paperbacks.

Simeon, R., \& Turgeon, L. (2007). Constitutional Design and the Construction of Democracy. In J. I. Dominguez, \& A. Jones (Eds.). The Construction of Democracy: Lessons from Practice and Research. Baltimore: The Johns Hopkins University Press.

Snyder, J. (2000). From Voting to Violence: Democratization and Nationalist Conflict. New York: Norton.

Sunstein, C. R. (1988). Constitutions and Democracies: An Epilogue. In J. Elster, \& R. Slagstad (Eds.), Constitutionalism and Democracy. Studies in Rationality and Social Change. Cambridge: Cambridge University Press.

The 1945 Constitution of the Republic of Indonesia and the Act Number 24 of 2003 on the Constitutional Court of the Republic of Indonesia. (2003). Jakarta: Secretariat General of the Constitutional Court of the Republic of Indonesia.

Tilly, C. (2007). Democracy. Cambridge: Cambridge University Press.

Vickers, A. (2005). A History of Modern Indonesia. Cambridge: Cambridge University Press.

Wilson, C. (2008). Ethno-Religious Violence in Indonesia: From Soil to God. Oxon: Routledge.

Notes

Note 1. By saying "all democracies have constitutions" it does not mean that Mueller denies that there are democratic countries that have not a written constitution, for example Great Britain. Mueller wants to stress that a written constitution is "an essential feature of constitutional democracy" (Mueller 1997, 65 \& 85). 
Note 2. Although I agree with Dennis C. Mueller that a written constitution is important in constitutional democracy (Mueller 1996, 43; 1997, 85), I tend to argue that it does not necessary whether a country has a written or unwritten constitution as long as there are regulations and guarantees for harmony and stability in a divided society. For the context of this essay, I agree with Scott Gordon who argues that "constitutionalism has little to do with the existence of a written constitution" (Gordon 1999, 5). 